Canadian Science Publishing

Canadian Journal of Earth Sciences Revue canadienne des sciences de la Terre

\title{
Chemical weathering east and west of the emerging Caledonides in the Silurian-early Devonian, with implications for climate
}

\begin{tabular}{|r|l|}
\hline Journal: & Canadian Journal of Earth Sciences \\
\hline Manuscript ID & cjes-2015-0156.R2 \\
\hline Manuscript Type: & Article \\
\hline Date Submitted by the Author: & 15 -Feb-2016 \\
\hline Complete List of Authors: & $\begin{array}{l}\text { Kiipli, Enli; Institute of Geology at Tallinn University of Technology, } \\
\text { Kiipli, Tarmo; Tallinn University of Technology } \\
\text { Kallaste, Toivo; Tallinn University of Technology } \\
\text { Märss, Tiiu; Tallinn University of Technology }\end{array}$ \\
\hline Keyword: & clay, climate, Al/Ti, Laurentia, Silurian \\
\hline & \multicolumn{2}{|l}{} \\
\hline
\end{tabular}


1 Chemical weathering east and west of the emerging Caledonides in the

2 Silurian - early Devonian, with implications for climate

3

4 Enli Kiipli ${ }^{1}$, Tarmo Kiipli ${ }^{1}$, Toivo Kallaste ${ }^{1}$ and Tiiu Märss ${ }^{1}$

$5{ }^{1}$ Institute of Geology at Tallinn University of Technology, Ehitajate tee

6 5, 19086 Tallinn, Estonia.

7 Corresponding author: e-mail address: enli.kiipli@ttu.ee (E. Kiipli); tel. $8 \quad+37258843833$.

9

Abstract

The late Llandovery (Silurian) - early Lochkovian (Devonian) climate of the tropical zone is tracked considering orogenesis, global glaciation events and cratonic drift. Mineral and chemical compositions of clay fractions of Canadian (the Franklinian Basin) and Estonian (the Baltoscandian Basin) sedimentary rocks from different sides of the emerging Caledonides were studied, using clay as an index of climatic conditions of the provenance area. Illite is the main clay mineral with addition of orthoclase, muscovite and chlorite in both regions. Authigenic chert is present in some Canadian sections. The similarity of clay minerals and elemental composition in the two regions suggest common chemical weathering conditions. Nevertheless, the Al/Ti ratio of the $<1$ micron clay fraction, the proxy for climate's aridity-humidity and weathering intensity, reveals differences. The Franklinian Basin in Laurentia shows a shift of climate from humid to semi-humid in pace with the uplift of the Caledonides. The sub-meridional mountain chain in the east reduced the amount of rainfall and, therefore, caused drier climate than could have been expected from the low latitudinal position of the area. The material from the Baltoscandian Basin reveals semi-arid and arid climate for most of the Silurian. Although the southern part of 
the Fennoscandian Shield was situated in desert latitudes, the evidence

from the provenance of clay suggests that the climate was not fully arid.

In Baltoscandia, co-variation between low $\mathrm{Al} / \mathrm{Ti}$ of clay and negative shifts of $\delta^{13} \mathrm{C}$ of marine carbonates is recorded at some stratigraphical levels suggesting link between humid climatic episodes in mainland and waning of glaciers at the South Pole.

Key words: clay, climate, Al/Ti, Laurentia, Baltica, Silurian

\section{Introduction}

The Caledonian orogeny affected the climate of Baltica and Laurentia in the Silurian (Fig. 1). Precipitation changed in accordance with the rise of mountain chains. Also, the short-term global events indicated by excursions of carbon isotopes of carbonate (Saltzman 2005; Kaljo et al. 1998) and oxygen isotopes of apatite (Lehnert et al. 2010), were superimposed on regional climatic features. The aim of the present study was to characterize the climate of the equatorial zone west of the emerging Caledonides in Laurentia and the arid tropical zone east of the Caledonides in Baltica. The lithology and mineralogical-chemical composition of clay in the Baltoscandian and Franklinian sedimentary basins were compared. The clay contained characteristic mineral and chemical compositional signatures gained in the process of chemical weathering in the terrestrial provenance. The parent rock may have had a local imprint on the chemical composition of the clay that formed, but these differences were masked by erosional mixing. When climate changed, the compositional differences in clay chemistry changed simultaneously in the same direction, resulting in a new average. The comparison between temporally different averages, preserved in sedimentary record, allows interpretation of alterations in weathering conditions. 


\section{Geological background}

The Franklinian Basin was situated in the northern part of the Laurentia paleocontinent, comprising the northernmost Greenland and extending 1,500-2,000 km into the Canadian Arctic Archipelago (Figs. 1; 2). The basin was in the equatorial zone from the Ordovician until the Devonian (Cocks and Torsvik 2011). In the Silurian, it was a shallow-water carbonate basin. The likely provenance of terrigenous sediments was the Canadian Shield consisting of metamorphic and magmatic rocks. Some of the sediment may have come from the problematic land comprising the present-day Ellesmere and other smaller islands (Anfinson et al. 2012). The close position of Siberia to the Laurentia and Baltica suggested in the Silurian, was broken off by a new rifting in the Devonian (Golonka 2003). The thickness of the Silurian sediments in the Franklinian Basin reached 3-4 km (Thorsteinsson 1958). The first evidence of sediment input from the rising Caledonides occurred at the Ordovician-Silurian boundary in eastern North Greenland. Through the Llandovery an elongate fan system developed parallel to the Franklinian platform margin (Smith and Rasmussen 2008).

The Baltoscandian Basin was an epicontinental sea of carbonate accumulation in the southwestern part of the Baltica Plate. The main part of the craton was situated between latitudes $35^{\circ} \mathrm{S}$ and $10^{\circ} \mathrm{S}$ in the early Silurian, moving towards the equator with the speed of about 80-100 $\mathrm{km} / \mathrm{Ma}$ and crossing the boundaries of climatic zones (Nikishin et al. 1996). Near the Silurian-Devonian transition, the direction of the movement changed (Cocks and Torsvik 2011). The terrigenous components and clay minerals for the Baltoscandian Basin formed on the flat, slightly uplifted Fennoscandian Shield (Fig. 3a). Contemporaneous with the development of the Caledonides the Fennoscandian Shield 
smoothly emerged and joined with the Sarmatian Shield (Fig. 1c), causing regression of the Baltoscandian Basin (Kaljo et al. 1977; Baarli et al. 2003; Nikishin et al. 1996). Thickness of the Silurian sediments varied from $200 \mathrm{~m}$ in Estonia up to $2-3 \mathrm{~km}$ in the deep southwestern part of the Baltoscandian Basin (Verniers et al. 2008). The Pechora Basin of the near-polar Urals was a good landmark for tracking the boundary between desert and the equatorial wet climate. In Pechora the upper Silurian limestones replaced the lower Silurian dolomites and evaporites (Baarli et al. 2003; Nikishin et al. 1996) in accordance with the northward drift of Baltica Plate. In the same interval, the Baltoscandian Basin moved within desert latitudes, from $30^{\circ} \mathrm{S}$ to $15^{\circ} \mathrm{S}$.

\section{Material}

We characterised chemical weathering through chemical and mineral compositions of clay fractions $<1$ micron. Our investigation showed that neither Canadian nor Estonian samples were heated or damaged by secondary changes, as they dispersed well in dissolving procedures.

\subsection{The Canadian material}

The rock samples were collected by one of the authors (T. M.) during her expedition to the Canadian Arctic Archipelago in 1994. The samples from the sections of Cornwallis and Baillie Hamilton islands represent transition of deep and shallow facies, where limestones alternate with graptolitic shales (Fig. 2b) (Melchin and Holmden 2006). The stratigraphy of the Canadian samples follows Märss et al. (1998) and Märss and Männik (2013). The Cape Phillips Formation (Fm.) of Baillie Hamilton Island ranges from the upper Telychian through Ludfordian. The formation contains alternations of microlaminated mudstone (graptolitic shale), siltstone and limestone (grainstone, rudstone, 
117 floatstone) layers of 5-30 cm in thickness. The Barlow Inlet Fm. of 118 Cornwallis Island, Read Bay south outcrop, represents the Prridoli Series

119 and consists of limestone, dolomite and shale. The Devonian (Lochkovian) Sophia Lake Fm. and the overlying Snowblind Bay Fm., in the northern section of Read Bay consist of limestone and dolomite with siltstone and sandstone interbeds and conglomerate (Fig. 4).

\subsection{The Baltoscandian material}

The Baltoscandian material comes from the shallow shelf of Estonia, Latvia and Lithuania (Fig. 3b). The majority of samples, representing the Wenlock, Ludlow and lower Přidoli Series (Kaljo et al. 1998), were collected from the Ohesaare core from the Saaremaa Island, the upper Llandovery (Telychian) samples come from the Kirikuküla and Paatsalu cores from mainland Estonia. The Kolka-54 core from western Latvia and the Taurage core from Lithuania represent the lower part of the Lochkovian. The lithology, mainly limestone, dolomite and marlstone, is shown in a composite section (Fig. 5.) To ensure that the clay comes from a single provenance area, shallow-shelf samples were used. The deepshelf material from different sources brought into the Baltoscandian Basin by currents (Kiipli et al. 2009) would have made the comparison uncertain and was, therefore, excluded.

\section{Methods}

The clay fraction was mainly separated from calcareous material. The samples were treated with $1 \mathrm{~N} \mathrm{HCl}$. For dissolution of $100 \mathrm{~g}$ of calcite, 2 litres of acidic solution was needed. The insoluble residue was settled for 24 hours in a $0.1 \%$ Na-pyrophosphate solution. The unsettled part, the clay fraction $<1 \mu \mathrm{m}$, was centrifuged and then dried. For the Canadian samples, the initial sample weight was about $100 \mathrm{~g}$. The insoluble 
residue, in the amount of $20 \%$, consisted mainly of clay fraction and sand- and silt-sized quartz grains. The organic carbon content varied from 0.5 to $5 \%$, treatment with $\mathrm{H}_{2} \mathrm{O}_{2}$ was used for these samples.

The Estonian samples were more clayey thereby $30-50 \mathrm{~g}$ of the initial calcareous material was taken. The insoluble residue consisted of clay and silt without sand and organic matter.

The clay fraction was analysed for chemical and mineral composition. Pressed clay pellets were subjected to X-ray fluorescence (XRF) analysis using the Bruker AXS S-4 spectrometer at the Institute of Geology at TUT. The detection limit for the main elements heavier than $\mathrm{P}$ was $0.01 \%$, for lighter elements, $0.1 \%$. The chemical analyses used in Figs 4 and 5 are given as calculated averages of the global series in Table 1. The mineral composition of the clay fraction was analysed by X-ray diffractometry (XRD).

As a proxy for climate and intensity of chemical weathering, the $\mathrm{Al}_{2} \mathrm{O}_{3} / \mathrm{TiO}_{2}$ ratio of clay fraction was used. $\mathrm{Al}$ and $\mathrm{Ti}$ are bound together in clay-forming process and the characteristic $\mathrm{Al} / \mathrm{Ti}$ ratio is preserved in sedimentary basins (Ronov and Migdisov 1965). Al and Ti are immobile elements in near-neutral conditions, but their migration diverges according to the $\mathrm{pH}$ of the environment. $\mathrm{Al}$ goes into the solution at $\mathrm{pH}$ $<4$ and $\mathrm{pH}>10$, whereas $\mathrm{Ti}$ is mobile at $\mathrm{pH}<2$. In clays, Ti can replace $\mathrm{Al}$ in the crystal lattice depending on the intensity of chemical weathering. Temperature and precipitation determine the intensity of chemical weathering which is stronger in the humid and weaker in the arid climate (van de Kamp 2010). Investigating different geological sections, Akul'shina (1976) elaborated the empirical relationship for the $\mathrm{Al}_{2} \mathrm{O}_{3} / \mathrm{TiO}_{2}$ (here referred to as $\mathrm{Al} / \mathrm{Ti}$ ) ratio and climate: $\mathrm{Al} / \mathrm{Ti}<20$ indicates humid climate and intense chemical weathering; the ratio $>30$ points to arid climate and weak chemical weathering. Semi-humid and 
semi-arid conditions stay between the values of 20 and 30 . The Al/Ti of the clay fraction separated from carbonate rocks of the Baltoscandian Basin has previously been applied in differentiating humid and arid climates of the Upper Ordovician and Silurian in the Fennoscandian Shield (Kiipli et al. 2012).

\section{Results}

\subsection{Clay fraction of Franklinian Basin}

The main clay mineral of the clay fraction is illite. Few Telychian samples reveal traces of kaolinite. Clay mineral content depended on authigenic chert (Thorsteinsson 1958) from Baillie Hamilton and northern Cornwallis islands. From Llandovery to Ludlow, the amount of quartz (mainly chert) reaches $74 \%$ in the fraction $<1 \mu \mathrm{m}$. In the Přidoli chert is lacking and only $2 \%$ of terrigenous quartz was detected in the Read Bay sections (Fig. 4). To eliminate the silica influence, the Al-normalisation of element contents was used. The $\mathrm{K}_{2} \mathrm{O} / \mathrm{Al}_{2} \mathrm{O}_{3}$ ratio in clay stays rather constantly around 0.33 . A shift towards lower values occurs in the Devonian, as the $\mathrm{MgO}$ content increases. The rise in $\mathrm{MgO}$ starts in Přidoli time and is associated with the rising chlorite content of up to $2-3 \%$. In the lower Devonian, the $\mathrm{MgO}$ reaches $10.6 \%$ and magnesian chloritesmectite, corrensite, is detected in addition to chlorite. Dispersed orthoclase is present in the clay fraction, its content reaching $5-6 \%$ in the upper Přidoli and Lochkovian. The content of muscovite polytype $2 \mathrm{M}_{1}$ is around $10 \%$ in the chert-free upper interval. The $\mathrm{Al} / \mathrm{Ti}$ ratio increases upwards, from 12 in the Telychian up to 25 in the Pridoli. The trend is interrupted by random higher and lower values.

\subsection{Clay fraction of the Baltoscandian Basin}


The clay fraction of the Baltoscandian Basin (Fig. 5) consists of illite, muscovite $2 \mathrm{M}_{1}$, minor chlorite, quartz and orthoclase - very similar to the Canadian clay, excluding the component of authigenic chert in the Canadian material. Authigenic hematite adds red hue to the Devonian section, whereas the Silurian rocks are grey. The chemical composition of the clay fraction is rather uniform through the Silurian, shown by Alnormalised elements (Fig. 5). Some fluctuations occur in the lower Telychian and in the upper Wenlock. The $\mathrm{Al} / \mathrm{Ti}$ ratio is between 25 and 30 during most of the Silurian and in the Lower Devonian. In the lower Telychian Rumba Fm. the $\mathrm{Al} / \mathrm{Ti}$ ratio below 20 is recorded in the Estonian Kirikuküla and Paatsalu cores (Fig. 6).

\section{Discussion}

6.1. Climate at the equator west of the Caledonides

Oceanic illite, chlorite and kaolinite are generally related to latitude (Fütterer 2000). In the Franklinian Basin, the main Silurian clay mineral is illite. Kaolinite, characteristic of equatorial humid climate, is absent, though the weathering provenance was situated near the equator. In the Telychian, before the main orogeny, low $\mathrm{Al} / \mathrm{Ti}$ ratio indicates humidity, but the lack of kaolinite (traces, found in Telychian samples) shows that the humidity was only moderate. In accordance with the uplift of the Caledonides, the clay fraction gained more non-weathered mineral particles pointing to the increasing influence of the mountains. Also, the rising $\mathrm{Al} / \mathrm{Ti}$ ratio shows weakening of chemical weathering and movement towards semi-humid and semi-arid climates from Sheinwoodian up to the end-Silurian (Fig. 4). Very likely, the rising submeridional mountain ranges hindered the reach of moist trade winds to the Canadian Shield (Fig. 1b, c).

6.2. Climate in the tropics east of the Caledonides 
232 In Baltoscandia, starting from the Telychian, silt and sand fractions 233 gained more muscovite (Viiding et al. 1983). Also, in the clay fraction, 234 the content of orthoclase and muscovite $2 \mathrm{M}_{1}$ increased, pointing to the 235 rising influence of the Caledonides from the middle Wenlock on (Fig. 5). $236 \mathrm{Al} / \mathrm{Ti}$ shows semi-arid/arid climate. The Baltica's drift sets the southern Fennoscandian Shield at the desert latitudes (Fig. 1). The lithology of the Pechora Basin in the northern side of the Baltica Plate helps to refine the positions. In the Llandovery, preceding the Caledonian Orogeny, the Baltoscandian sections consisted of lime- and marlstone, the Pechora Basin of dolomites and evaporites (Nikishin et al. 1996). The Pechora area was situated around $15^{\circ} \mathrm{S}$ and the Baltoscandian Basin about 1,500 $\mathrm{km}$ southwards, near $30^{\circ} \mathrm{S}$ (Fig. 1a). In the Wenlock (Fig. 1b), the replacement of evaporites and dolomites by limestones-marlstones (Baarli et al. 2003) indicates the reach of Pechora to the equatorial humid belt. At the same time, the dolomite and occurrences of gypsum in the Podolia, Ukraine, (Tsegelnyuk and Bukatchuk 1974) show advance of tropical desert in Baltoscandia (Fig. 1b,c). In the latest Silurian, the southern part of the Fennoscandian Shield together with the adjacent Baltoscandian Basin may have approached, but not entered, the equatorial zone, indicated by replacement of dolomite by limestones-marlstones of the latest Silurian (Kaljo et al. 1970). Also, the decline in Al/Ti ratio of the latest Přidoli suggests semi-humid conditions (Fig. 5). The semiarid/arid climate of the Fennoscandian desert, not achieving strongly arid conditions, indicates presence of modest rainfalls. South-east winds from southern seas regulated the moist regime in Fennoscandia, similar to monsoons in present-day India.

\subsection{Devonian changes}


In the early Devonian, the erosion of the Caledonides prevailed bringing about changes in chemical and physical weathering in Baltica and Canada. Mg-corrensite in the Lochkovian (lowermost Devonian) clay suggests new environmental conditions of clay formation in Canada. Occurrence of saline lagoons (Drits and Kossovskaya 1990) or intramontane shallow water bodies, similar to those of western Norway in the Devonian (Fossen et al. 2008), may be possible. In Baltoscandia, the Ordovician-Silurian carbonate basin was replaced by siliciclastic dominated setting. In Estonia, kaolinite appears in the Pragian (Kemeri Regional Stage) (Viiding et al. 1983), indicating an equatorial location of clay provenance.

\subsection{Short-term global climatic events}

During the Silurian the global climate was affected by several cooling events reflected by positive excursions of $\delta^{13} \mathrm{C}$ pointing to south polar glaciations (Saltzman 2005). In contrast, the negative excursions may correspond to retreat of ice-sheets. In Baltoscandia a co-variation between low $\mathrm{Al} / \mathrm{Ti}$ of clay and the negative shift of $\delta^{13} \mathrm{C}$ of marine carbonates is recorded in the lower Telychian (Fig. 6). Humidity of the early Telychian (turriculatus graptolite zone) was probably caused by a global climatic warming episode (Kiipli et al. 2012). Other co-variations between negative excursions of $\mathrm{Al} / \mathrm{Ti}$ and $\delta^{13} \mathrm{C}$ occur in the lower Homerian (lundgreni graptolite zone) and Gorstian (nilssoni graptolite zone). Compared to the lower Telychian, the latter two shifts of $\mathrm{Al} / \mathrm{Ti}$ are less pronounced. In Canada, there is no co-variation between $\delta^{13} \mathrm{C}$ and $\mathrm{Al} / \mathrm{Ti}$, comparing the $\mathrm{Al} / \mathrm{Ti}$ with isotope data published by Märss et al. (1998). Probably, the influence of the Caledonides overshadows the possible changes in clay composition related to short-term global climatic events. 
7. Conclusions

Clay fractions in Silurian carbonates of the equatorial Franklinian and desert-to-subequatorial Baltoscandian basins were similar in composition, and lacked kaolinite. The Al-normalised $\mathrm{K}_{2} \mathrm{O}, \mathrm{MgO}$ and $\mathrm{Fe}_{2} \mathrm{O}_{3}$ values were comparable in both areas. Still, the $\mathrm{Al} / \mathrm{Ti}$ ratio helps to refine climatic differences in time and space. In Baltoscandia in the early Telychian and Laurentia in the upper Telychian and Sheinwoodian, regional climate was more humid than in later times. In Baltoscandia Telychian continental humidity appears to have been due to a short-term global climatic warming event. In the Franklinian Basin that weathering event was overprinted by equatorial humidity. From Wenlock time, both basins show increasing aridity and reduced chemical weathering. In the Franklinian Basin the climate became semi-humid, while the Baltoscandia — south Fennoscandia was arid to semi-arid. The high Caledonian Mountain chain that separated the two areas, in addition to latitude, controlled precipitation and regional climates.

\section{Acknowledgements}

This study is a contribution to the International Geoscience Programme (IGCP) 591. The rock samples come from the collection of the Institute of Geology at Tallinn University of Technology. We are grateful to $\mathrm{H}$. Pohl-Raidla for the linguistic help, A. Kleesment for her consultations on Devonian, G. Baranov for his help with the figures and to U. Toom for her help with the rock samples. Two anonymous reviewers are thanked for their constructive comments.

References 
Akul'shina, E.P. 1976. Methods for determining weathering conditions, sedimentation and post-sedimentary transformations according to clay minerals. In Clay minerals as indicators of rock forming conditions. Edited by E.P. Akul'shina. Nauka, Novosibirsk, pp. 937 (in Russian).

Anfinson, O.A., Leier, A.L., Gaschnig, R., Embry, A.F., and Dewing, K. 2012. U-Pb and $\mathrm{Hf}$ isotopic data from Franklinian Basin strata: insights into the nature of Crockerland and the timing of accretion, Canadian Arctic Islands. Canadian Journal of Earth Science, 49: 1316-1328.

Baarli, B.G., Johnson, M.E., and Antoshkina, A.I. 2003. Silurian stratigraphy and paleogeography of Baltica. In Silurian lands and seas. Edited by E. Landing and M.E. Johnson. New York State Museum Bulletin, 493: pp. 3-34.

Cocks, L.R.M., and Torsvik, T.H. 2011. The Palaeozoic geography of Laurentia and western Laurussia: A stable craton with mobile margins. Earth-Science Reviews, 106: 1-51.

Drits, V.A., and Kossowskaya, A.G. 1990. Clay minerals: smectites, mixed-layer silicates. Nauka, Moscow, pp. 214 (in Russian).

Fossen, H., Dallmann, W., and Andersen, T.B. 2008. The mountain chain rebounds and founders. In The making of a land-Geology of Norway. Edited by I.B. Ramberg, I. Bryhni, A. Nøttvedt, and K. Rangnes. Norsk Geologisk Forening, Trondheim, pp. 232-259.

Fütterer, D.K. 2000. The solid phase. of marine sediments. In Marine geochemistry. Edited by H.D. Schulz and M. Zabel. SpringerVerlag Berlin Heidelberg, pp.1-22.

Golonka, J., Bocharova, N.Y., Ford, D., Edrich, M.E. Bednarczyk, J., and Wildharber, J. 2003. Paleogeographic reconstructions and basins 
development of the Arctic. Marine and Petroleum Geology, 20: 211-248.

Kaljo, D., and Jürgenson, E. 1977. Sedimentary facies of the East Baltic Silurian. In Facies and fauna of the Baltic Silurian. Edited by D. Kaljo. Academy of Sciences of the Estonian SSR, Institute of Geology, Tallinn, pp. 122-148 (in Russian with English abstract).

Kaljo, D., and Martma, T. 2000. Carbon isotopic composition of Llandovery rocks (East Baltic Silurian) with environmental interpretation. Proceedings of the Estonian Academy of Sciences Geology, 49: 267-283.

Kaljo, D., Kiipli, T., and Martma, T. 1998. Correlation of carbon isotope events and environmental cyclicity in the East Baltic Silurian. New York State Museum Bulletin, 491: 297-312.

Kaljo, D., Klaamann, E., Nestor, H., Einasto, R., and Jürgenson, E. 1970. Facies and evolution of the basin. In Silur Estonii. Edited by D. Kaljo. Valgus, Tallinn, pp. 301-317 (in Russian with English abstract).

Kiipli, E., Kiipli, T., and Kallaste, T. 2009. Reconstruction of currents in the Mid-Ordovician-Early Silurian central Baltic Basin using geochemical and mineralogical indicators. Geology, 37: 271-274.

Kiipli, E., Kiipli, T., Kallaste, T., and Siir, S. 2012. $\mathrm{Al}_{2} \mathrm{O}_{3} / \mathrm{TiO}_{2}$ ratio of the clay fraction of Late Ordovician-Silurian carbonate rocks as an indicator of palaeoclimate of the Fennoscandian Shield. Palaeogeography, Palaeoclimatology, Palaeoecology, 365-366: 312-320.

Kiipli, T., Kallaste, T., and Nestor, V. 2010a. Composition and correlation of volcanic ash beds of Silurian age from the eastern Baltic. Geological Magazine, 147: 895-909. 
Kiipli, T., Kallaste, T., Nestor, V., and Loydell, D.K. 2010b. Integrated Telychian (Silurian) K-bentonite chemostratigraphy and biostratigraphy in Estonia and Latvia. Lethaia, 43: 32-44.

Kiipli, T., Einasto, R., Kallaste, T., Nestor, V., Perens, H., and Siir, S. 2011. Geochemistry and correlation of volcanic ash beds from the Rootsiküla Stage (Wenlock-Ludlow) in the eastern Baltic. Estonian Journal of Earth Sciences, 60: 207-219.

Lehnert, O., Männik, P., Joachimski, M.M., Calner, M., and Frýda, J. 2010. Palaeoclimate perturbations before the Sheinwoodian glaciation: A trigger for extinctions during the 'Ireviken Event'. Palaeogeography, Palaeoclimatology, Palaeoecology, 296: 320331.

Loydell, D.K. 2012. Graptolite biozone correlation charts. Geological Magazine, 149: 124-132

Märss, T., and Männik, P. 2013. Revision of Silurian vertebrate biozones and their correlation with the conodont succession. Estonian Journal of Earth Sciences, 62: 181-204.

Märss, T., Caldwell, M., Gagnier, P., Goujet, D., Männik, P., Martma, T., and Wilson, M. 1998. Distribution of Silurian and Lower Devonian vertebrate microremains and conodonts in the Baillie-Hamilton and Cornwallis island sections, Canadian Arctic. Proceeding of the Estonian Academy of Sciences Geology, 47: 51-76.

Melchin, M.J., and Holmden, C. 2006. Carbon isotope chemostratigraphy of the Llandovery in Arctic Canada: Implications for global correlation and sea-level change. GFF, 128: 173-180.

Nikishin, A.M., Ziegler, P.A., Stephenson, R.A., Cloething, S.A.P.L., Furne, A.V., Fokin, P.A., Ershov, A.V., Bolotov, S.N., Korotaev, M.V., Alekseev, A.S., Gorbachev, V.I., Shipilov, E.V., Lankreijer, A., Bembinova, E.Yu., and Shalimov, I.V. 1996. Late Precambrian 
to Triassic history of the East European Craton: dynamics of sedimentary basin evolution. Tectonophysics, 268: 23-63.

Ronov, A.B., and Migdisov, A.A. 1965. Main features of the geochemistry of elements-hydrolysates in processes of weathering and sedimentation. Geochimiya, 2: 131-157 (in Russian).

Saltzman, M.R. 2005. Phosphorus, nitrogen, and the redox evolution of the Paleozoic oceans. Geology, 33: 573-576.

Smith, M.P., and Rasmussen, J.A. 2008. Cambrian-Silurian development of the Laurentian margin of the Iapetus Ocean in Greenland and related areas. In The Greenland Caledonides: evolution of the northeast margin of Laurentia. Edited by A.K. Higgins, J.A. Gilotti, and M.P. Smith. The Geological Society of America Memoir, 202: Boulder, Colorado, USA, pp. 137-167.

Thorsteinsson, R. 1958. Cornwallis and Little Cornwallis islands district of Franklin Northwest territories. Geological Survey of Canada Memoir, 294: pp. 134.

Tsegelnyuk, P.D., and Bukatchuk, P.D. 1974. The SW slope of the Ukrainian Shield. In Stratigraphy of the USSR v. IV, part 1. Edited by D.E. Aisenverg. Naukova Dumka, Kiev, pp. 156-173 (in Ukrainian).

Van de Kamp, P. 2010. Arkose, subarkose, quartz sand, and associated muds derived from felsic plutonic rocks in glacial to tropical humid climates. Journal of Sedimentary Research, 80: 895-918.

Verniers, J., Maletz, J., Křiž, J., Žigaite, Ž., Paris, F., Schönlaub, H.P., and Wrona, R. 2008. Silurian. In The geology of Central Europe, Volume 1: Precambrian and Palaeozoic. Edited by T. McCann. Geological Society London, pp. 249-302.

Viiding, H.A., Kleesment, A.E., Konsa, M., Heinsalu, H., and Jürgenson, E. 1983. Evolution of the terrigenous component of sedimentary 
rocks of the southern slope of the Baltic Shield. In Terrigenous minerals of the Baltic sedimentary rocks. Edited by H.A. Viiding. Academy of Sciences of Estonia, Tallinn, pp. 7-22 (in Russian).

Tables

Table 1 . Average values, in wt $\%$, of main chemical elements of the clay fraction.

Figures

Fig. 1. Silurian palaeogeography around the colliding continents.

Positions of Baltica, Laurentia and Siberia in Llandovery (a), Wenlock (b) and latest Silurian (c) are composed using data from Cocks and Torsvik (2011) and Golonka et al. (2003). Lithologic data are included from Baarli et al. (2003), Nikishin et al. (1996), Tsegelnyuk and Bukatchuk (1974), Cocks and Torsvik (2011), Golonka et al. (2003). Wind directions are proposed by analogy with present day world.

Fig. 2. Location map of Arctic Canada with star marking the study area (a); sampling points in the Cornwallis and Baillie Hamilton islands of the Canadian Arctic Archipelago, the facies after Melchin and Holmden (2006) (b).

Fig. 3. Location map with late Silurian palaeogeographic setting of the Baltioscandia, facies compiled after Baarli et al. (2003) and Kaljo and Jürgenson (1977) (a); sampling points (b). 
Fig. 4. Franklinian Basin. Stratigraphy (from Märss et al. 1998), selected Al-normalized ratios of main elements, and minerals (in \%) of the clay fraction of the composite outcrop section of the Baillie Hamilton and Cornwallis islands.

Fig. 5. Baltoscandian Basin. Stratigraphy, selected Al-normalized ratios of main elements, and minerals (in \%) of the clay fraction of the composite core section of Estonia-Latvia-Lithuania. Depths of global stage boundaries (in $\mathrm{m}$ ) for the Ohesaare core - from Kaljo et al. (1998); depths of formations of the Kirikuküla core - from Kaljo and Martma (2000).

Fig. 6. The $\mathrm{Al}_{2} \mathrm{O}_{3} / \mathrm{TiO}_{2}$ of terrigenous clay fraction $v s . \delta^{13} \mathrm{C}$ of marine carbonate of the Estonian composite section of the Baltoscandian Basin. The grey ribbons show intervals of co-variation of negative excursions of $\mathrm{Al} / \mathrm{Ti}$ and $\delta^{13} \mathrm{C}$. The isotopes of the Ohesaare core from Jaani to Kaugatuma stages from Kaljo et al. (1998); of the Ohesaare cliff, Ohesaare Stage - from Kaljo et al. (2012); of the Kirikuküla core, Late Llandovery - from Kaljo and Martma (2000). Depths and stage boundaries, in meters, of the Ohesaare core, - from Kiipli et al. (2010a; 2010b; 2011). Abbreviations: regional stages-Tž, Tilže; OH, Ohesaare; KG, Kaugatuma; KR, Kuressaare; PD, Paadla; RT, Rootsiküla; JG, Jaagarahu; JN, Jaani; AD, Adavere; global stages-Ludf., Ludfordian; Gorst., Gorstian. Formations (Fm.) in italic. Names of graptolite biozones after Loydell (2012). 

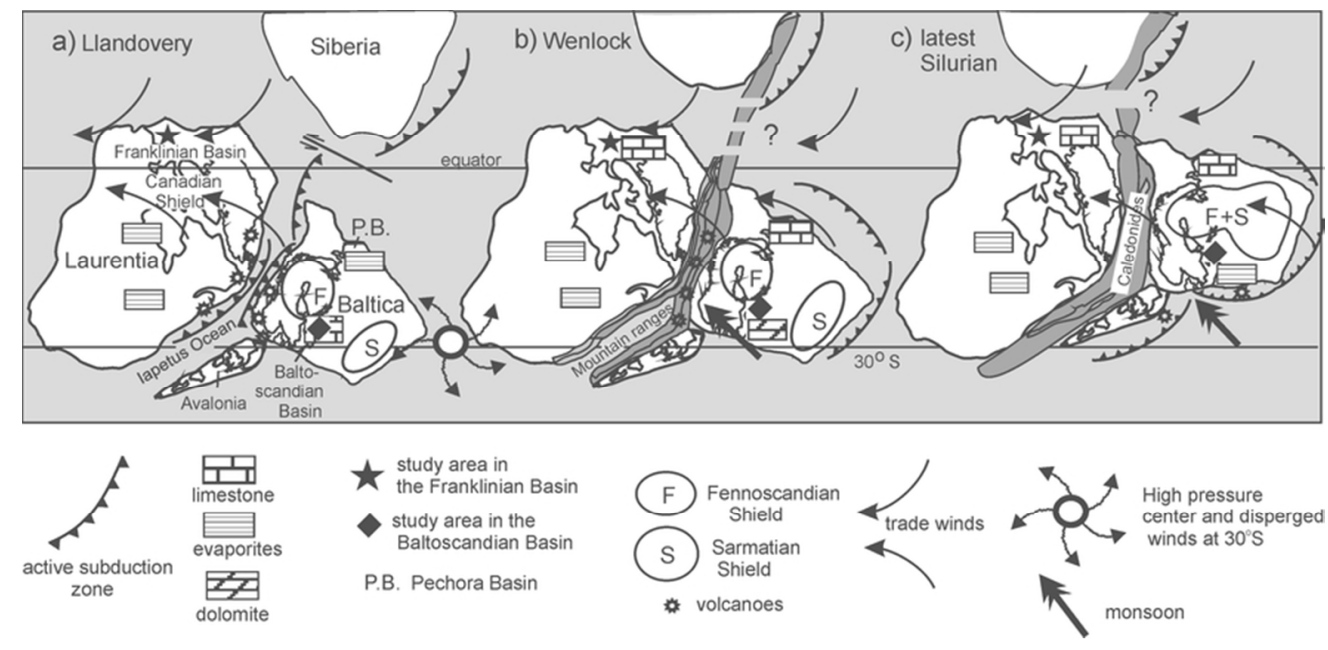

Fig. 1. Silurian palaeogeography around the colliding continents. Positions of Baltica, Laurentia and Siberia in Llandovery (a), Wenlock (b) and latest Silurian (c) are composed using data from Cocks and Torsvik (2011) and Golonka et al. (2003). Lithologic data are included from Baarli et al. (2003), Nikishin et al.

(1996), Tsegelnyuk and Bukatchuk (1974), Cocks and Torsvik (2011), Golonka et al. (2003). Wind directions are proposed by analogy with present day world.

$74 \times 36 \mathrm{~mm}(300 \times 300$ DPI $)$ 


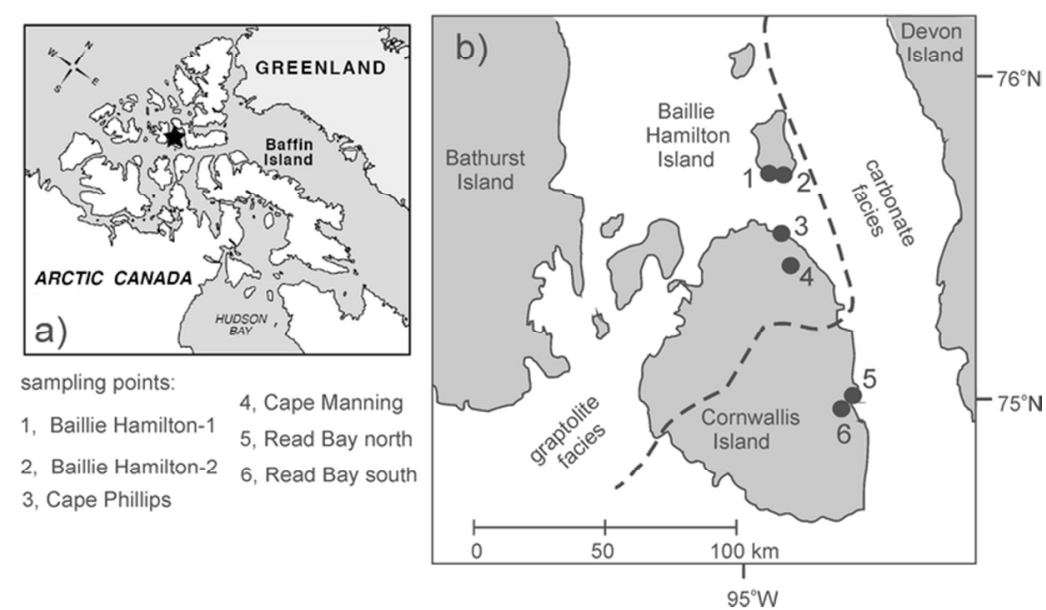

Fig. 2. Location map of Arctic Canada with star marking the study area (a); sampling points in the Cornwallis and Baillie Hamilton islands of the Canadian Arctic Archipelago, the facies after Melchin and Holmden (2006) (b). $81 \times 43 \mathrm{~mm}(300 \times 300 \mathrm{DPI})$ 


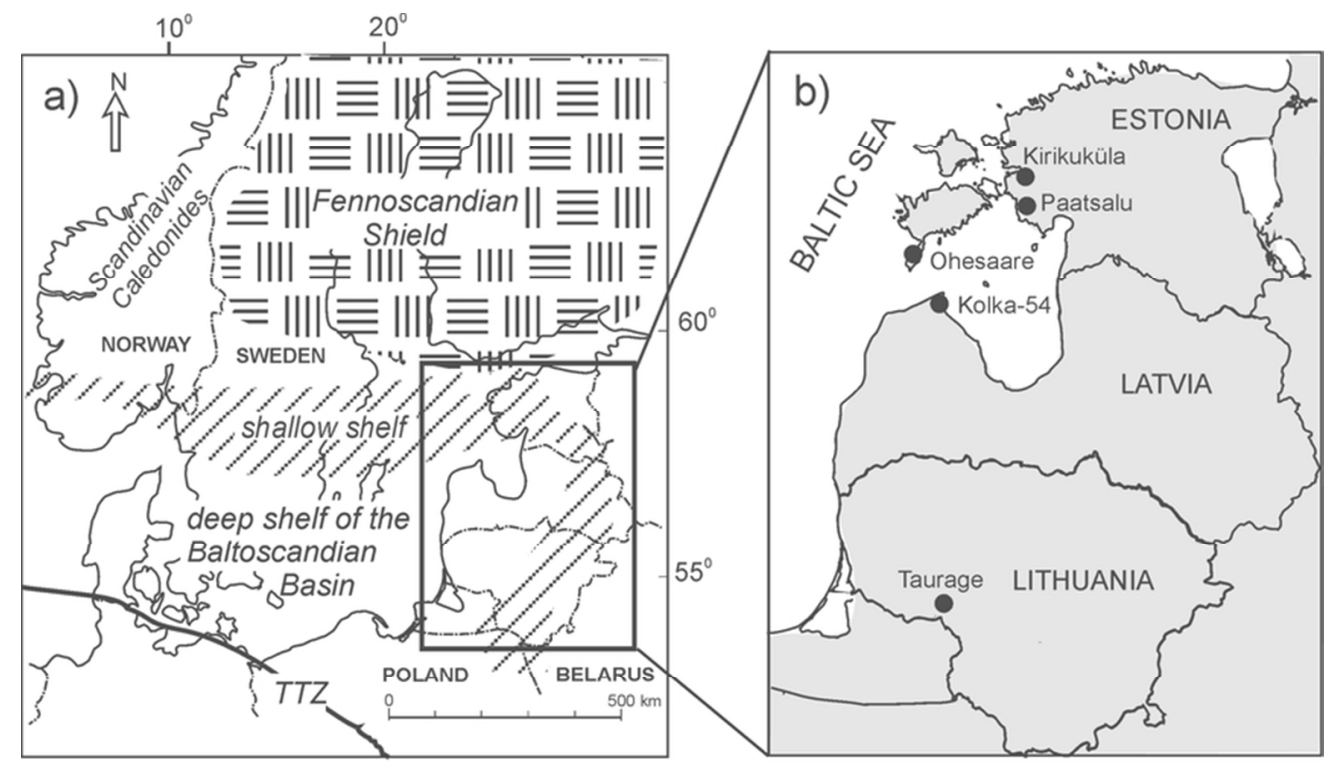

TTZ, Teisseyre-Tornquist Zone

Fig. 3. Location map with late Silurian palaeogeographic setting of the Baltioscandia, facies compiled after Baarli et al. (2003) and Kaljo and Jürgenson (1977) (a); sampling points (b).

$72 \times 44 \mathrm{~mm}$ (300 x 300 DPI) 


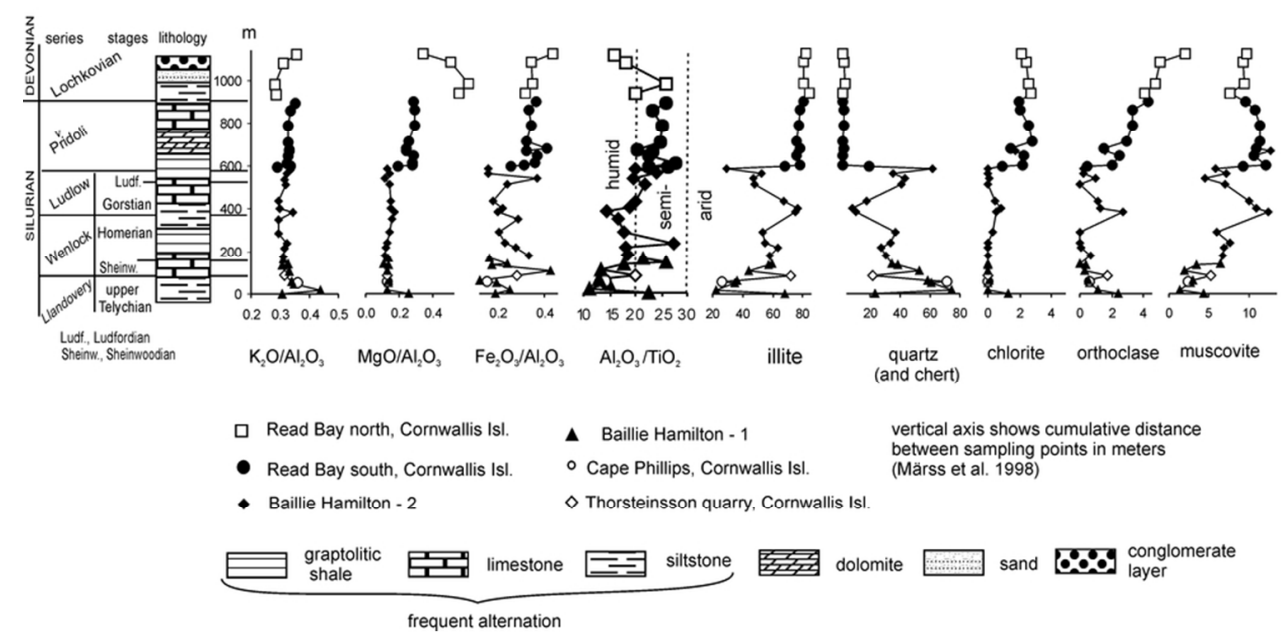

Fig. 4. Franklinian Basin. Stratigraphy (from Märss et al. 1998), selected Al-normalized ratios of main elements, and minerals (in \%) of the clay fraction of the composite outcrop section of the Baillie Hamilton and Cornwallis islands.

$86 \times 41 \mathrm{~mm}(300 \times 300 \mathrm{DPI})$ 


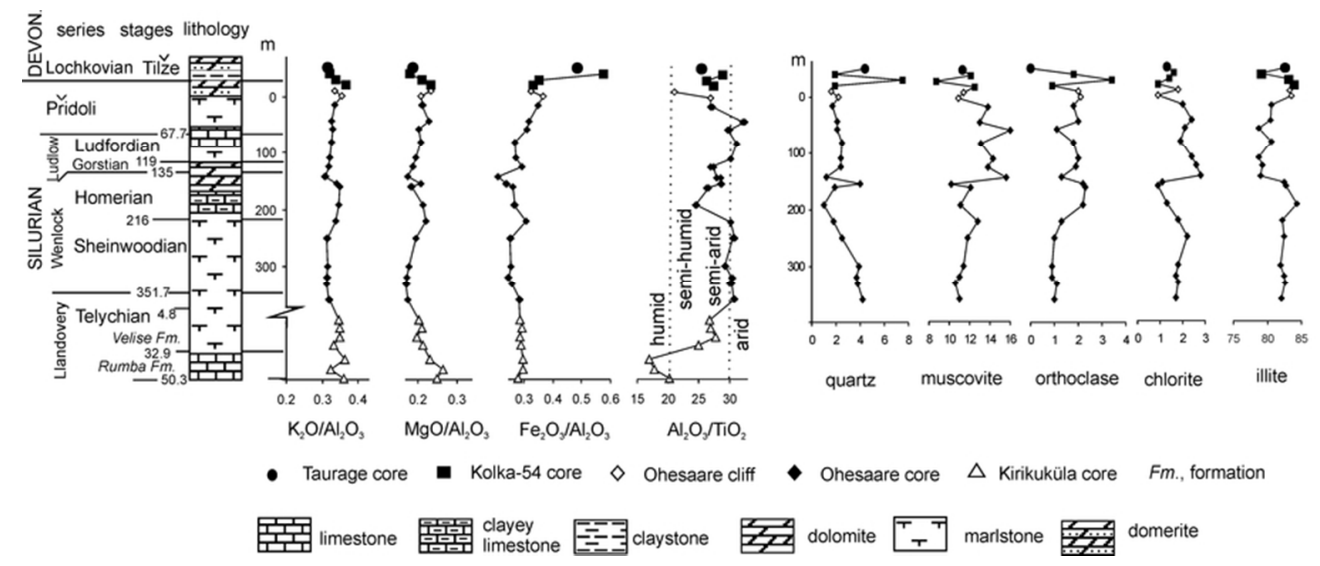

Fig. 5. Baltoscandian Basin. Stratigraphy, selected Al-normalized ratios of main elements, and minerals (in $\%$ ) of the clay fraction of the composite core section of Estonia-Latvia-Lithuania. Depths of global stage boundaries (in $\mathrm{m}$ ) for the Ohesaare core - from Kaljo et al. (1998); depths of formations of the Kirikuküla core - from Kaljo and Martma (2000).

$77 \times 32 \mathrm{~mm}(300 \times 300 \mathrm{DPI})$ 
Fig. 6

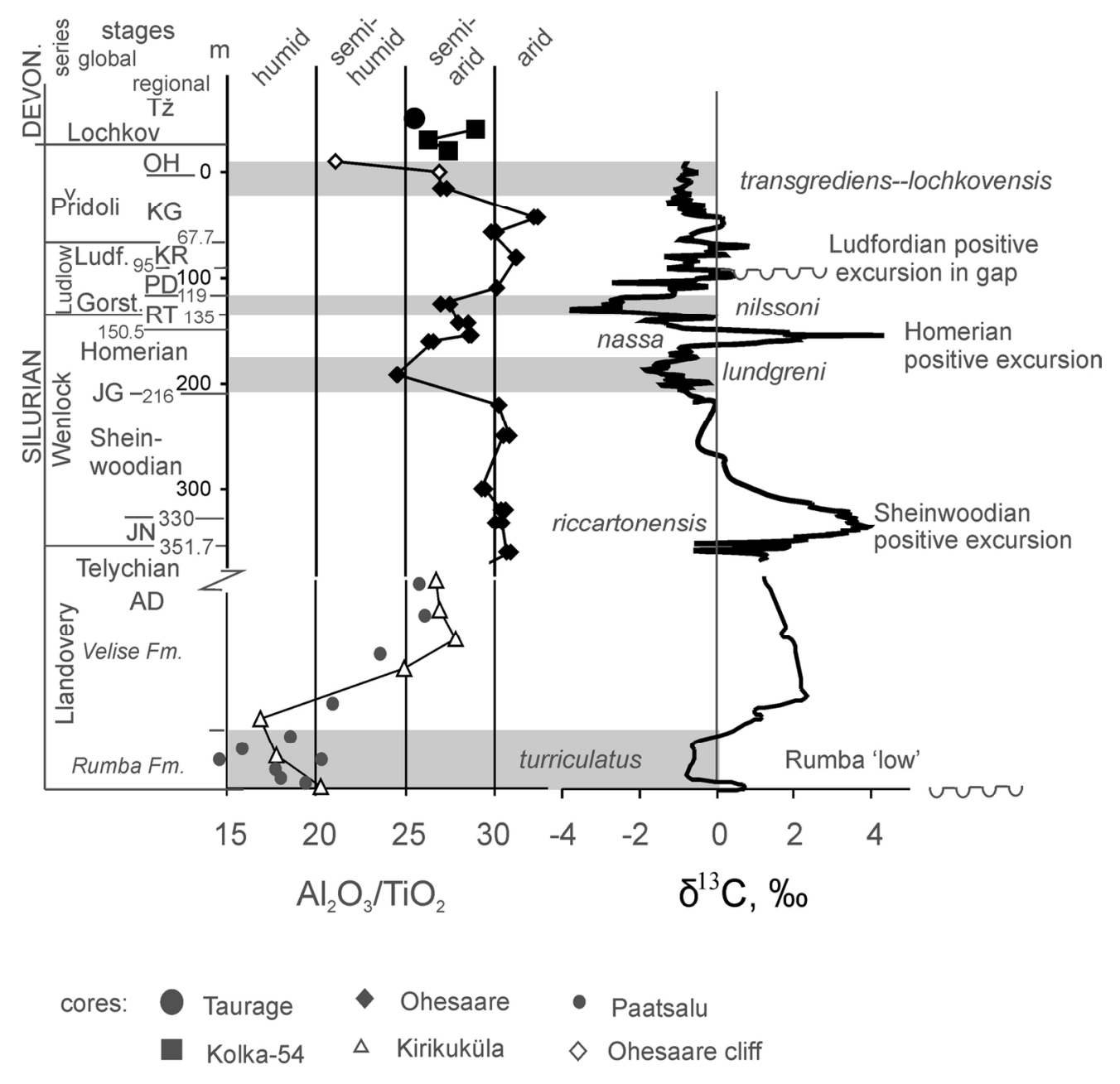

Fig. 6. The Al2O3/TiO2 of terrigenous clay fraction vs. $813 \mathrm{C}$ of marine carbonate of the Estonian composite section of the Baltoscandian Basin. The grey ribbons show intervals of co-variation of negative excursions of $\mathrm{Al} / \mathrm{Ti}$ and $\delta 13 \mathrm{C}$ (see text for explanations). The isotopes of the Ohesaare core from Jaani to Kaugatuma stages from Kaljo et al. (1998); of the Ohesaare cliff, Ohesaare Stage - from Kaljo et al. (2012); of the Kirikuküla core, Late Llandovery - from Kaljo and Martma (2000). Depths and stage boundaries, in meters, of the Ohesaare core, - from Kiipli et al. (2010a; 2010b; 2011). Abbreviations: regional stages-Tž, Tilže; $\mathrm{OH}$, Ohesaare; KG, Kaugatuma; KR, Kuressaare; PD, Paadla; RT, Rootsiküla; JG, Jaagarahu; JN, Jaani; AD, Adavere; global stages-Ludf., Ludfordian; Gorst., Gorstian. Formations (Fm.) in italic. Names of graptolite biozones after Loydell (2012).

$144 \times 172 \mathrm{~mm}(300 \times 300 \mathrm{DPI})$ 
Table 1. Average values, in wt $\%$, of main chemical elements of the clay fraction

\begin{tabular}{ccccccccccccccc}
\hline & $\mathrm{n}$ & $\mathrm{H}_{2} \mathrm{O}$ & $\mathrm{SiO}_{2}$ & $\mathrm{Al}_{2} \mathrm{O}_{3}$ & $\mathrm{~K}_{2} \mathrm{O}$ & $\mathrm{Fe}_{2} \mathrm{O}_{3}$ & $\mathrm{MgO}$ & $\mathrm{CaO}$ & $\mathrm{TiO}_{2}$ & $\mathrm{MnO}$ & $\mathrm{S}$ & $* \mathrm{Na}_{2} \mathrm{O}$ & $* \mathrm{P}_{2} \mathrm{O}_{5}$ & $* \mathrm{Cl}^{2}$ \\
\hline Baltoscandian Basin & & & & & & & & & & & & & & \\
Lochkov & 3 & 8.5 & 48.7 & 20.3 & 6.6 & 9.6 & 3.9 & 0.6 & 0.76 & 0.04 & 0.01 & 0.2 & 0.3 & 0.3 \\
Pridoli & 9 & 9.2 & 49.1 & 20.7 & 7.0 & 6.9 & 4.5 & 0.1 & 0.74 & 0.03 & 0.14 & 0.2 & 0.7 & 0.2 \\
Ludlow & 5 & 10.2 & 47.9 & 21.6 & 7.0 & 6.1 & 4.2 & 0.2 & 0.74 & 0.03 & 0.25 & 0.2 & 0.5 & 0.2 \\
Wenlock & 18 & 9.7 & 49.3 & 21.8 & 7.1 & 5.6 & 4.1 & 0.1 & 0.76 & 0.03 & 0.12 & 0.2 & 0.4 & 0.2 \\
u.Telychian, Velise Fm. & 8 & 9.7 & 49.3 & 20.8 & 7.2 & 6.5 & 4.5 & 0.1 & 0.82 & 0.03 & 0.03 & 0.2 & 0.4 & 0.2 \\
1. Telychian, Rumba Fm. & 15 & 9.5 & 48.4 & 20.8 & 7.2 & 6.0 & 4.9 & 0.1 & 1.18 & 0.04 & 0.17 & 0.3 & 0.4 & 0.2 \\
Franklinian Basin & & & & & & & & & & & & & & \\
Lochkov & 5 & 11.3 & 46.2 & 17.9 & 5.5 & 6.5 & 9.0 & 0.3 & 0.93 & 0.03 & 0.16 & 0.3 & 0.5 & 0.2 \\
Pridoli & 8 & 10.5 & 47.7 & 20.0 & 6.5 & 6.7 & 5.3 & 0.2 & 0.84 & 0.04 & 0.21 & 0.2 & 0.7 & 0.1 \\
Ludlow & 7 & 10.0 & 60.2 & 15.0 & 4.8 & 3.2 & 2.2 & 0.3 & 0.79 & 0.01 & 0.77 & 0.3 & 0.6 & 0.2 \\
Wenlock & 9 & 10.7 & 61.6 & 13.7 & 4.3 & 3.4 & 1.8 & 0.1 & 0.71 & 0.01 & 0.72 & 0.2 & 0.9 & 0.1 \\
Telychian & 5 & 10.1 & 72.1 & 8.6 & 2.9 & 1.5 & 1.5 & 0.2 & 0.55 & 0.01 & 0.61 & 0.2 & 0.3 & 0.1 \\
\hline & & & & & & & & & & & & & &
\end{tabular}

n--number of samples

*--residue of chemicals from the clay separation

Fm., Formation 